\title{
Pretranslational Regulation of the Synthesis of the Third Component of Complement in Human Mononuclear Phagocytes by the Lipid A Portion of Lipopolysaccharide
}

\author{
Robert C. Strunk, Alexander S. Whitehead, and F. Sessions Cole \\ Department of Pediatrics, National Jewish Hospital and Research Center, University of Colorado Medical School, Denver, Colorado \\ 80206; Division of Cell Biology, Department of Medicine, Children's Hospital; Joint Program in Neonatology, Brigham and Women's \\ Hospital; and Department of Pediatrics, Harvard Medical School, Boston, Massachusetts 02115
}

\begin{abstract}
The third component of complement (C3) is a plasma glycoprotein with a variety of biologic functions in the initiation and maintenance of host response to infectious agents. While the hepatocyte is the primary source of plasma C3, mononuclear phagocytes contribute to the regulation of tissue availability of C3. Lipopolysaccharide (LPS), a constituent of cell walls of gramnegative bacteria, consists of a polysaccharide moiety (core polysaccharide and $\mathbf{O}$ antigen) covalently linked to a lipid portion (lipid A). Using metabolic labeling with ${ }^{35}$ S|methionine, immunoprecipitation, and SDS-polyacrylamide gel electrophoresis, we examined the effects of LPS on synthesis of C3 by human mononuclear phagocytes as well as synthesis of the second component of complement (C2), factor B, lysozyme, and total protein. LPS increased C3 synthesis 5-30-fold without affecting the kinetics of secretion of $\mathrm{C} 3$ or the synthesis of $\mathrm{C2}$, lysozyme, or total protein. Factor B synthesis was consistently increased by LPS. Experiments with lipid A-inactivated LPS (alkaline treated), LPS from a polysaccharide mutant strain, and lipid $X$ (a lipid A precursor) indicated that the lipid A portion is the structural element required for this effect. Northern blot analysis demonstrated at least a fivefold increase in C3 mRNA in LPStreated monolayers, which suggests that the regulation of the increase in C3 synthesis is pretranslational. C2 mRNA and factor B mRNA were increased approximately twofold. The availability of specific gene products in human mononuclear phagocytes that respond to LPS should permit understanding of the molecular regulation of more complex functions of these cells elicited by LPS in which multiple gene products are coordinately expressed.
\end{abstract}

\section{Introduction}

Mononuclear phagocytes are an important extrahepatic source of several plasma proteins, including components of the complement cascade (1-3). Cells isolated from several species including the human synthesize and secrete the third component of complement (C3). ${ }^{1} \mathrm{C} 3$ is a $180-\mathrm{kD}$ disulfide-linked two-chain

Address reprint requests to Dr. Strunk, National Jewish Hospital and Research Center.

Received for publication 12 February 1985 and in revised form 7 May 1985

1. Abbreviations used in this paper: bp, base pair(s); $\mathrm{C} 2$, second component of complement; $\mathrm{C} 3$, third component of complement; cDNA complementary DNA; FB, factor B; LPS, lipopolysaccharide; proC3, single-chain precursor protein.

J. Clin. Invest.

(C) The American Society for Clinical Investigation, Inc.

$0021-9738 / 85 / 09 / 0985 / 06 \quad \$ 1.00$

Volume 76, September 1985, 985-990 glycoprotein that is essential for opsonization of microorganisms, generation of anaphylatoxic activities, and the assembly of the membrane attack complex by either the classical or alternative pathways (4). In the human, its plasma concentration is the highest of any complement component $(150-300 \mathrm{mg} / 100 \mathrm{ml})$ and is regulated as an acute phase reactant. C3 is synthesized as a single-chain precursor protein (proC3) of $\sim 200 \mathrm{kD}$, which subsequently undergoes signal peptide cleavage and proteolytic cleavage by a plasminlike enzyme to its native two-chain form $(5,6)$. Although the hepatocyte is the primary source of plasma $\mathrm{C} 3$, studies of $\mathrm{C} 3$ synthesis by monocytes from C3-deficient individuals (7) and synovial tissue from patients with rheumatoid arthritis (8) suggested that regulation of C3 synthesis is independent in monocytes and hepatocytes and that mononuclear phagocyte production of $\mathrm{C} 3$ plays a significant role in controlling tissue concentrations of this protein.

Lipopolysaccharide (LPS), a constituent of cell walls of gramnegative bacteria, is a potent activator of humoral and cellular immunity $(9,10)$. Structurally, LPS consists of two polysaccharide moieties (the core polysaccharide and $\mathrm{O}$ antigen polysaccharide) covalently linked to a lipid region (lipid A). While the polysaccharide portion of the molecule is extremely immunogenic, the lipid portion elicits most of the other biologic effects of LPS. In mononuclear phagocytes, LPS enhances tumoricidal capacity (11) and increases production of superoxide anion (12), hydrolytic enzymes (13), fibroblast growth factors (14), prostaglandin $E_{2}(15)$, and factor $B$ synthesis (FB) $(16,17)$. The hydroxymyristate moiety at position two of the lipid A precursor, lipid $\mathrm{X}$, has recently been shown to be a structural requirement for the enhancement of cytotoxic capacity and prostaglandin $E_{2}$ production in mouse macrophages (15).

Using incorporation of radiolabeled amino acids into $\mathrm{C} 3$ protein detected by gel diffusion, Thorbecke et al. (18) demonstrated originally that the production of $\mathrm{C} 3$ in liver fragments (probably hepatocytes) was increased by injection of adult mice or monkeys with LPS 6-24 h before collection of the livers. More recently, the effect of LPS on complement production by macrophages has been studied by three groups. Miyama et al. (16) and Sundsmo et al. (17) demonstrated that LPS stimulated production of FB in mouse peritoneal macrophages, but Passwell et al. (19) could not detect an effect of LPS on the production of functional second component of complement (C2) by human monocyte-derived macrophages. The availability of cDNA probes for $\mathrm{C} 3$ and other complement proteins produced by human monocytes ( $\mathrm{C} 2$ and $\mathrm{FB}$ ) permitted studies of the molecular mechanisms that account for the effects of LPS on complement synthesis. In addition, the use of structurally altered LPS allowed characterization of the structural requirements for this response. In this report, we provide data that LPS increases C 3 synthesis in human mononuclear phagocytes, that the regulation of this 
effect is pretranslational, and that the lipid A portion of the LPS molecule is required for this effect.

\section{Methods}

LPS preparations. LPS isolated by different extraction procedures and from different organisms were examined: Escherichia coli 026:B6 (TCA extraction) (Sigma Chemical Co., St. Louis, MO), E. coli 0111:B4 (both TCA and Westphal extractions) (Difco Laboratories, Detroit, MI), Salmonella minnesota wild type and a polysaccharide-deficient mutant (Westphal extraction) (List Biological Laboratories, Campbell, CA), and E. coli K235 (Westphal extraction) (a generous gift from Michael Pabst, National Jewish Hospital and Research Center). Preliminary studies indicated that all the LPS preparations produced similar stimulation of C3 synthesis. Except where indicated, LPS extracted from $E$. coli 0111 : B4 by the Westphal procedure was used to avoid the potential effects of lipid A-associated protein in materials extracted by the TCA procedure. Lipid A-inactivated LPS was generated by mild alkaline hydrolysis (20). Purified lipid X (21) was the generous gift of Christian R. H. Raetz (Dept. of Biochemistry, University of Wisconsin, Madison, WI). Before incubation with monocyte monolayers, all LPS preparations were diluted in LPS-free phosphate-buffered saline (PBS) (by limulus assay, sensitive to $0.01 \mathrm{ng} \mathrm{LPS} / \mathrm{ml}$ ), sonicated, and diluted into tissue culture media that contained between 0.1 and $1 \mathrm{ng} / \mathrm{ml}$ of LPS.

Cell cultures, biosynthetic labeling, and immunoprecipitation. Monocyte monolayers were established and maintained by either of two previously described methods $(22,23)$. The effects of LPS were similar on monolayers established by either method. Monolayers were incubated at $37^{\circ} \mathrm{C}$ with LPS in serum-free medium or in medium that contained $5 \%$ heat-inactivated $\left(30 \mathrm{~min}\right.$ at $\left.56^{\circ} \mathrm{C}\right)$ autologous serum. Inclusion of heat-inactivated $\left(120 \mathrm{~min}\right.$ at $56^{\circ} \mathrm{C}$ ) fetal bovine serum (Hazleton Dutchland, Inc., Denver, PA, or Flow Laboratories, McLean, VA) during incubation with LPS abrogated the effect of LPS on C3 synthesis. For most experiments, monolayers maintained for $7 \mathrm{~d}$ in culture were used. Cell number was determined by counting nuclei as previously described (24), and cell viability assessed by measuring lactate dehydrogenase release (25). Biosynthetic labeling experiments were performed by incubating monocyte monolayers at $37^{\circ} \mathrm{C}$ in methionine-free medium (Dulbecco's modified Eagle's medium 80-0072; Gibco Laboratories, Grand Island, $\mathrm{NY})$ containing $\left.{ }^{35} \mathrm{~S}\right]$ methionine $(500 \mu \mathrm{Ci} / \mathrm{ml})$ (specific radioactivity $\sim 1,000 \mathrm{Ci} / \mathrm{mmol}$, New England Nuclear, Boston, MA) for $60 \mathrm{~min}$ (26).

At the end of the pulse period, monolayers were rinsed and either lysed by freeze thawing as previously described (26) or, in pulse-chase experiments, transferred to medium containing $\sim 1000$-fold excess of cold methionine and incubated for varying time periods (chase periods). At the end of each chase interval, extracellular media were harvested and monolayers lysed. Total protein synthesis was estimated by trichloroacetic acid precipitation of aliquots of lysates (27). Incorporation of ${ }^{35}$ S]methionine into $\mathrm{C} 3$ protein was dependent upon concentration of radiolabeled amino acid from $50 \mu \mathrm{Ci} / \mathrm{ml}$ to $500 \mu \mathrm{Ci} / \mathrm{ml}$ in the medium in both LPS and control monolayers. When LPS was added to control lysate, no difference in the recovery of radiolabeled $\mathrm{C} 3$ protein was observed. Cell lysates and media were immunoprecipitated with excess specific antibody using excess formalin fixed $S$. aureus (Cowan strain 2, IgGsorb, The Enzyme Center, Malden, MA) as previously described (26). IgG fractions of goat antisera to C3, FB, and lysozyme were obtained from Atlantic Antibody, Westbrook, ME, and sheep antiserum to human C2 from Seward Laboratory, London, England. Immunoprecipitates were subjected to SDS-polyacrylamide gel electrophoresis, and the resulting gels fixed, impregnated with Enhance (New England Nuclear), dried, and exposed at $-70^{\circ} \mathrm{C}$ to Kodak XAR-5 film (Eastman Kodak Co., Rochester, NY). Incorporation of $\left[{ }^{35} \mathrm{~S}\right]$ methionine into individual immunoprecipitated proteins was determined in gel slices after digestion with 15\% hydrogen peroxide for $16 \mathrm{~h}$ and addition of ScintiVerse I (Fischer Scientific Co., Fair Lawn, NJ) (28).

Hemolytic titration of $C 3$. Hemolytically active $\mathrm{C} 3$ was detected in serum-free media as previously described (23). Using these methods, as few as $10^{6}$ molecules of $\mathrm{C} 3$ or $\sim 20 \mathrm{ng}$ of $\mathrm{C} 3$ protein can be detected. The sensitivity and specificity of the hemolytic titration of $\mathrm{C} 3$ were not affected by LPS.

Isolation of C3 complementary DNA ( $C D N A)$ clones. Approximately $5 \times 10^{4}$ clones of an adult human liver cDNA library (29) were plated on $82-\mathrm{mm}$ nitrocellulose filters and screened by a modification of the procedure of Grunstein and Hogness (30) using a mouse C 3 cDNA clone (the generous gift of Dr. Morinobu Takahashi, Kanazawa University, Kanazawa, Japan). The mouse $\mathrm{C} 3 \mathrm{cDNA}$ insert was radiolabeled by nick translation (31) and hybridized with filter-bound DNA under standard conditions (32). After hybridization, filters were washed in $30 \mathrm{mM}$ sodium chloride $/ 3 \mathrm{mM}$ sodium citrate at $65^{\circ} \mathrm{C}$ for $1 \mathrm{~h}$, dried, and exposed to Kodak XAR-5 film (Eastman Kodak Co.). Of over 100 positive hybridization signals, eight clones were selected, colony purified, and plasmid DNA was prepared (33). The insert from the largest clone, pC3AL1, was excised with Pst1. The pC3AL1 insert has an internal Pst 1 site and comprises two fragments of $\sim 600$ and $\sim 300$ base pairs (bp). The 600-bp fragment was cloned into the $M 13$ vector $\mathrm{mpl1}$, and nucleotide sequence was determined by the dideoxy chain termination procedure of Sanger et al. (34). Using sequence homology to the published sequence of murine C3 (35), this fragment of pC3ALl was found to encompass C3 alpha chain coding sequence from amino acid residue 279 to amino acid residue 479 , which includes the thiol ester portion of the molecule and was used for all experiments described in this report.

$R N A$ extraction, oligo dT chromatography, and Northern blot analysis. For RNA extraction, monolayers were established in $100-\mathrm{mm}$ siliconized, glass Petri dishes. Total cellular RNA was extracted from monolayers by lysis with guanidinium thiocyanate and cesium chloride density gradient ultracentrifugation (36). From 1 to $1.5 \mu \mathrm{g}$ of RNA were isolated from $10^{5}$ adherent monocytes, and no difference in recovery of RNA between LPS-treated and control monolayers was observed. Poly At RNA was purified from equal amounts of total cellular RNA (usually 100-200 $\mu \mathrm{g}$ ) using oligo(dT)-cellulose (type 7, P-L Biochemicals, Inc., Milwaukee, WI), and subjected to Northern blot analysis (37) using single stranded (M13 mp11) cDNA probes radiolabeled by primer extended synthesis in the presence of ${ }^{32} \mathrm{P}$-nucleotides (dCTP, dATP, dGTP, dTTP, specific radioactivity $\sim 667 \mathrm{Ci} / \mathrm{mmol}$, New England Nuclear). The isolation and characterization of the cDNA probes for $\mathrm{C} 2$ (pC2-F2) (38) and FB (pBfA28) (29) have been previously described. Each of these probes has an internal Pst 1 site. The larger portion of each probe (for C2-F2, 1,200 bp, for pBfA28, 1,900 bp) was subcloned into the singlestranded vector $\mathrm{M} 13 \mathrm{mpl}$, and nucleotide sequence was determined by the dideoxy chain termination procedure of Sanger et al. (34) to verify that neither probe was altered during subcloning.

\section{Results}

Effect of LPS on the synthesis and secretion of C3, C2, FB, and lysozyme in human monocytes. To determine the effect of LPS on $\mathrm{C} 3$ production, monocyte monolayers from three individuals were incubated in the presence of $10 \mathrm{ng} / \mathrm{ml}$ to $1,000 \mathrm{ng} / \mathrm{ml}$ of LPS for $2 \mathrm{~d}$, and hemolytically active $\mathrm{C} 3$ in the media was measured. LPS increased C3 production in a concentration dependent fashion (Fig. 1) without causing significant changes in cell number (Table I) or viability. An eightfold variation in C3 production was noted in monocyte monolayers from different donors. Variability in enhancement in $\mathrm{C} 3$ production was not a function of the LPS preparation used but was rather a function of variability in response among donors.

To determine whether increased production of $\mathrm{C} 3$ resulted from a change in the secretion rate of $\mathrm{C} 3$, a change in the synthesis rate of $\mathrm{C} 3$, or both, biosynthetic labeling studies using $\left[{ }^{35}\right.$ S]methionine were performed. The effect of LPS $(500 \mathrm{ng} / \mathrm{ml}$ for $24 \mathrm{~h}$ ) on secretion and/or intracellular catabolism was determined by the rate of disappearance of intracellular proC 3 in a chase period after a 1-h pulse with $\left[{ }^{35}\right.$ S $]$ methionine (Fig. 2). 


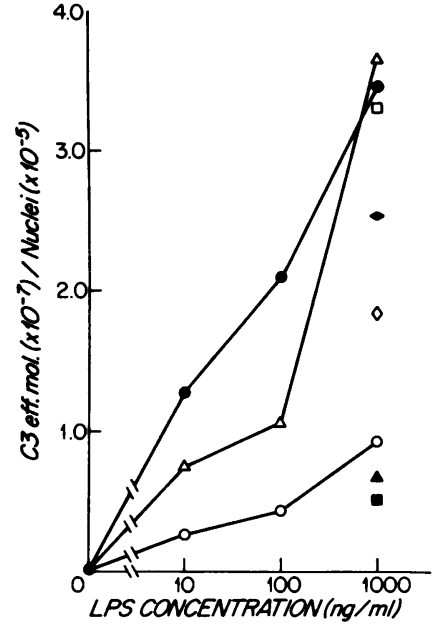

The time required for disappearance of proC3 was slightly delayed in LPS-treated monolayers. Thus, differences in kinetics of secretion could not account for the severalfold increase in C3 recovered in medium from LPS-treated monolayers.

In experiments to determine the effect of LPS on C3 synthesis, cells were incubated at $37^{\circ} \mathrm{C}$ with $\operatorname{LPS}(500 \mathrm{ng} / \mathrm{ml})$ for $24 \mathrm{~h}$ and then pulsed for $1 \mathrm{~h}$ with $\left[{ }^{35} \mathrm{~S}\right]$ methionine. In $10 \mathrm{ex}-$ periments, LPS-treated cells synthesized 5-30-fold more proC3 (mean 17.9) than the controls (Table I). Increases in $\mathrm{C} 3$ protein in extracellular media were similar when determined either immunochemically or functionally, indicating that no increase in C3 specific functional activity occurred after incubation with LPS (Fig. 3). Synthesis of C2, lysozyme, and total protein was not affected (Table I and Fig. 3). Synthesis of FB was increased from 2- to 55-fold. The increase in the synthesis rate of $\mathrm{C} 3$ was detectable between 4 and $8 \mathrm{~h}$ after the start of the incubation with LPS and continued to increase through $48 \mathrm{~h}$ of incubation with LPS (data not shown). The LPS-induced increase in synthesis of C3 persisted for $48 \mathrm{~h}$ after removal of LPS. Monocyte

Table I. Effect of LPS on Synthesis of C3, FB, C2, and Total Protein, and Cell Number*

\begin{tabular}{lc}
\hline & LPS/control \\
\hline C3 synthesis & $17.9(5.3-30.2)$ \\
FB synthesis & $21.9(2.4-54.5)$ \\
C2 synthesis & $1.3(0.8-2.4)$ \\
Total protein synthesis $¥$ & $1.1(0.9-1.3)$ \\
Cell number§ & $0.9(0.4-1.3)$
\end{tabular}

\footnotetext{
* Monocyte monolayers were maintained from day 7 to 8 in medium alone or medium containing LPS, $500 \mathrm{ng} / \mathrm{ml}$. Data from six experiments presented as mean (range) of ratios of incorporation of $\left[{ }^{35} \mathrm{~S}\right]$ methionine into specific proteins $\left(\left[{ }^{35} \mathrm{~S}\right] \mathrm{methionine}\right.$ incorporation in individual gel slice divided by incorporation of $\left[{ }^{35} \mathrm{~S}\right]$ methionine into TCA insoluble protein in the same experiment). C3 protein accounted for $0.01 \%$ (LPS) and $0.0006 \%$ (control) of total protein synthesized by monolayers, FB $(0.0089 \%$ [LPS] and $0.0003 \%$ [control], and C2 (0.003\% [LPS] and $0.002 \%$ [control]).

$¥$ TCA insoluble radiolabeled protein synthesized by $\sim 10^{5}$ adherent cells during a 1-h pulse with $\left.{ }^{35} \mathrm{~S}\right]$ methionine $(500 \mu \mathrm{Ci} / \mathrm{ml})$.

$\S$ Number of nuclei determined by counting nuclei in cell lysate (24).
}
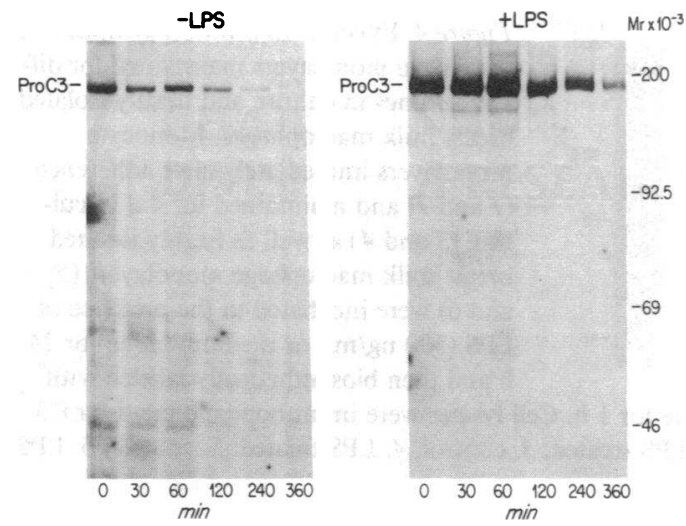

Figure 2. Effect of LPS on disappearance of proC3 in human blood monocytes. Monocyte monolayers from a single donor were incubated in medium alone (-LPS) or medium containing LPS $(500 \mathrm{ng} / \mathrm{ml})$ (+LPS) for $24 \mathrm{~h}$ and then pulsed with $\left.{ }^{35} \mathrm{~S}\right]$ methionine for $30 \mathrm{~min}$. At the end of the pulse period, monolayers were rinsed and transferred to medium containing no radiolabeled methionine and a 1,000-fold excess of unlabeled methionine. Monolayers were lysed at the end of the pulse period and at timed intervals thereafter, and the lysates immunoprecipitated with anti-C3 antibody. Using monolayers from three separate donors, the time required for disappearance of $50 \%$ proC3 was $0.8 \mathrm{~h}$ for the control (range 0.5-1.0) and $1.2 \mathrm{~h}$ for the LPS-treated monolayers (range 1.1-1.8).

monolayers from freshly adherent cells as well as tissue macrophages (freshly isolated from breast milk) responded to LPS (Fig. 4).

To determine the biosynthetic steps at which this increase was predominantly regulated, poly A+ RNA was isolated from monocyte monolayers incubated in the presence and absence of LPS and subjected to Northern blot analysis using human cDNA probes for $\mathrm{C} 3, \mathrm{C} 2$, and FB. Using soft laser densitometry, a 4.8-fold increase in C3 mRNA was observed in the LPS-treated monocytes, with a 2.5-fold increase in FB mRNA and a 1.8fold increase in C2 mRNA (Fig. 5).

Structural requirement for the effect of LPS on human monocyte C3 synthesis. To determine which portion of the LPS molecule was necessary for enhancement of $\mathrm{C} 3$ synthesis in human monocytes, the effects of distinct portions of the LPS molecule were examined. First, the lipid portion of the LPS molecule

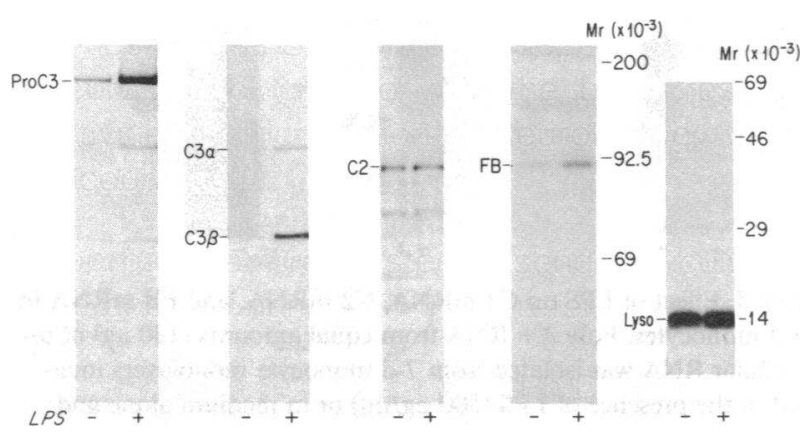

Figure 3. Effect of LPS on the synthesis of C3, C2, FB, and lysozyme (lyso). Monocyte monolayers were incubated in the presence of LPS $(500 \mathrm{ng} / \mathrm{ml})$ or medium alone for $24 \mathrm{~h}$, then biosynthetically labeled with $\left.{ }^{35} \mathrm{~S}\right]$ methionine for $1 \mathrm{~h}$. Cell lysates and media were immunoprecipitated as described above. 


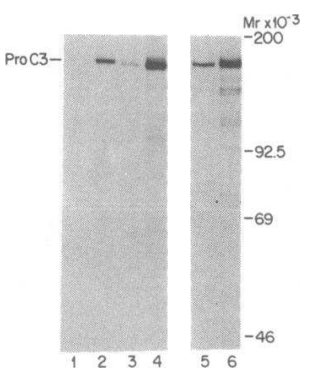
$\left.{ }^{35} \mathrm{~S}\right]$ methionine for $1 \mathrm{~h}$. Cell lysates were immunoprecipitated for $\mathrm{C} 3$. 1, control; 2, LPS treated; 3, control; 4, LPS treated; 5, control; 6, LPS treated.

(lipid A) was inactivated by mild alkaline hydrolysis (20). Lipid A inactivation was documented by the failure of this preparation to stimulate mitogenesis in mouse spleen cells. Lipid A-inactivated $\mathrm{LPS}\left(500 \mathrm{ng} / \mathrm{ml}, \sim 5 \times 10^{-8} \mathrm{M}\right)$ failed to enhance $\mathrm{C} 3$ synthesis (Fig. 6). Secondly, LPS from a polysaccharide-deficient mutant of $S$. minnesota $\left(500 \mathrm{ng} / \mathrm{ml}, \sim 5 \times 10^{-8} \mathrm{M}\right)$ increased C3 synthesis to the same extent as intact LPS (Fig. 6). Thirdly, lipid $\mathrm{X}$, an acylated monosaccharide thought to be a precursor of lipid A, was used at concentrations from 500 to $4,500 \mathrm{ng} / \mathrm{ml}$ $\left(\sim 7 \times 10^{-7}-7 \times 10^{-6} \mathrm{M}\right)$. Lipid X increased C3 production in a concentration-dependent fashion (Fig. 6). The molar amounts required for this effect were between 7 - and 75-fold greater than with LPS alone.

\section{Discussion}

We report that the lipid A portion of the LPS molecule stimulates C3 synthesis in primary monolayer cultures of human mononuclear phagocytes at a pretranslational level. The increase in C3 synthesis was specific, in that it occurred without a comparable effect on total protein synthesis or on synthesis of $\mathrm{C} 2$ or lysozyme. The increase in FB synthesis was similar to the effect of LPS on FB synthesis in mouse macrophages (17).

In several previous studies, in vitro and in vivo regulation of $\mathrm{C} 3$ production have been examined. Thorbecke et al. (18) first noted $\mathrm{C} 3$ synthesis by macrophages using rat peritoneal cells, and suggested that hydrocortisone modulated $\mathrm{C} 3$ synthesis. Using a well differentiated rat hepatoma cell line, Strunk et al.
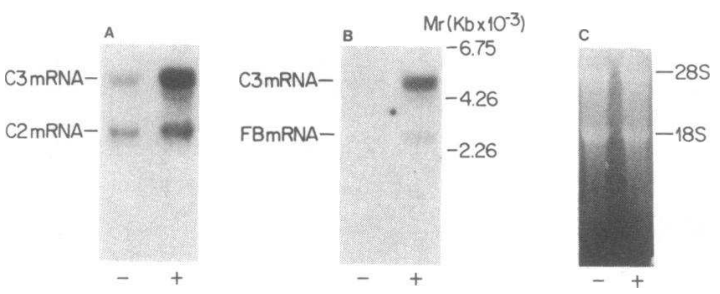

Figure 5. Effect of LPS on C3 mRNA, C2 mRNA, and FB mRNA in blood monocytes. Poly A+ RNA from equal amounts (130 $\mu \mathrm{g})$ of total cellular RNA was isolated from 7-d monocyte monolayers incubated in the presence of LPS $(500 \mathrm{ng} / \mathrm{ml})$ or in medium alone and subjected to Northern blot analysis. Nitrocellulose filters were hybridized with single-stranded cDNA probes for $\mathrm{C} 3$ and $\mathrm{C} 2$ or $\mathrm{C} 3$ and $\mathrm{FB}$. $(A)$ Control $(-)$ and LPS-treated $(+)$ monolayers; $(B)$ Control $(-)$ and LPS-treated $(+)$ monolayers; and $(C)$ Ethidium bromide-stained gel of ribosomal flow through from poly $A+$ isolation from control $(-)$ and LPS-treated (+) monolayers.

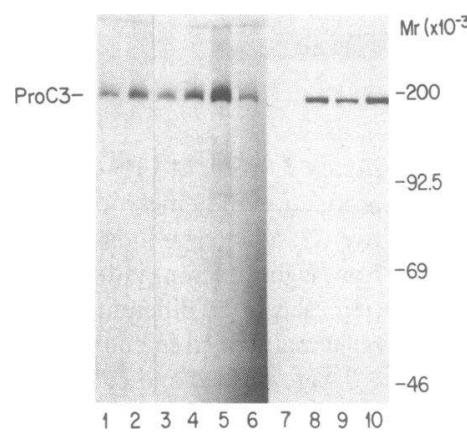

Figure 6. Effect of lipid A, lipid X, and polysaccharidedeficient LPS on C3 synthesis in blood monocytes. Monocyte monolayers were incubated with LPS or indicated LPS preparation for $24 \mathrm{~h}$ and biosynthetically labeled as described in Methods. 1, Control; 2, LPS $(500 \mathrm{ng} / \mathrm{ml}) ; 3$, lipid X, 500 $\mathrm{ng} / \mathrm{ml} ; 4$, lipid $X, 1,500 \mathrm{ng} /$ $\mathrm{ml} ; 5$, lipid $\mathrm{X}, 4,500 \mathrm{ng} / \mathrm{ml}$;

6, alkaline-treated LPS; 7, control; 8, E. coli 0111:B4 LPS (500 ng/ $\mathrm{ml}) ; 9, S$. minnesota wild type LPS (500 ng/ml); $10, S$. minnesota polysaccharide-deficient mutant.

(39) extended these observations when they observed a ninefold increase in functional $\mathrm{C} 3$ production in cells exposed to $4 \times 10^{-7}$ $M$ hydrocortisone. In that study, hydrocortisone specifically enhanced C3 production (production of C2 and C5 was not affected), an observation that suggested that $\mathrm{C} 3$ production is regulated independently from other complement proteins. More recently, in vivo activation of guinea pig macrophages by $C$. parvum resulted in increased C3 production (40). Although C3 production was modulated by different stimuli, the specific biosynthetic steps at which regulation occurs have not been determined in these studies.

LPS elicits a wide range of biologic responses in whole animals, including shock, increased resistance to infection, and fever $(9,10)$. LPS also elicits several cellular responses, including initiation of B lymphocyte proliferation (10) and activation of macrophages, as indicated by release of superoxide anion (12), prostaglandins (41), interleukin-1 (42), neutral proteases (13, 43), and monocyte-derived fibroblast growth factors (14). In addition, LPS stimulates several complex macrophage functions, including phagocytosis (44) and tumor cell killing (11). The molecular mechanisms that regulate cellular responses to LPS are not well understood, although the molecular biology of several of these mechanisms has been explored in vitro and in vivo. For example, when the murine B cell tumor line, BCL1, is stimulated by LPS, regulation of the membrane and secreted forms of the $\mu$-chain of IgM occurs at both transcriptional and translational levels (45). The transcriptional activation by LPS of kappa immunoglobulin genes in a B cell lymphoma line, 70Z/3, was accompanied by the appearance of a DNAse I hypersensitive site near a putative enhancer element (46). LPS also induced production of metallothionein-I mRNA in vivo in livers and kidneys of mice (47). Studies with transgenic mice localized the region responsible for the LPS induction of the metallothionein gene to the region 185-350 bp upstream from the $5^{\prime}$ end of the site of initiation of metallothionein transcription. Our studies suggest that LPS acts either by enhancing C3 mRNA transcription or stabilizing C3 mRNA, although the effect of LPS on C3 mRNA translation efficiency has not been rigorously examined. The availability of a specific biosynthetic marker of LPS response in macrophages may permit understanding of more complex macrophage responses to LPS, including phagocytosis or tumor cell killing.

There are several areas noted in these studies that require further exploration. First, the increase in C3 production to LPS in eight separate donors (Fig. 1) was highly variable. The vari- 
ability in response was not related to variability in base-line $\mathrm{C} 3$ production. Donor variability in other responses to LPS has been noted in studies of human neutrophil adhesion and monocyte production of acid phosphatase (Riches, D. H., and P. M. Henson, personal communication), but its significance remains unclear. The possibility that LPS responsiveness is under genetic regulation has been suggested by studies in the $\mathrm{C} 3 \mathrm{H} / \mathrm{HeJ}$ mouse strain (48-50). We have not yet detected human nonresponders. Secondly, the molecular biology of the LPS stimulus-response coupling is not known, but recent evidence has suggested that activation of protein kinase $\mathrm{C}$ may be involved (51). The kinetics of the effect of LPS on production of C3 in monocytes (initiation of the effect between 4 and $8 \mathrm{~h}$ ) and on $\mathrm{B}$ lymphocyte proliferation (stimulation of incorporation of $\left[{ }^{3} \mathrm{H}\right]$ thymidine between 7 and 14 h) (9) are consistent with a requirement for the production of one or more signals that are then responsible for the ultimate response. Third, it is not clear whether the increased C3 production occurs in all monocytes or in only a subpopulation. This question is of interest because of the possibility that LPS might stimulate $\mathrm{C} 3$ synthesis by increasing the amount of $\mathrm{C} 3$ synthesized per $\mathrm{C} 3$ producing cell, by increasing the number of $\mathrm{C} 3$ producing cells, or both. Such a mechanism might account for the differences in effects of LPS on C3 and C2 synthesis: subpopulations of cells that synthesize C2 (26) might be unresponsive to LPS. In situ hybridization with ${ }^{32} \mathrm{P}$-labeled or biotinylated cDNA probes for the proteins in question may provide an approach to this question. Finally, the significance of the increase in C2 mRNA in LPS-treated monolayers is unclear. It is possible that the difference between the effect of LPS on synthesis of $\mathrm{C} 2$ protein and the effect on $\mathrm{C} 2$ mRNA content represents control of $\mathrm{C} 2$ protein synthesis at the translational level.

The concentrations of LPS used in this study are comparable with those that elicit other effects on macrophages $(14,15)$ and are severalfold less than those previously used to activate lymphocytes $(9,10)$. The physicochemical form of LPS (e.g., in micelles or in membranes) and other lipophilic substances (e.g., high density lipoproteins) may modify the response of human mononuclear phagocytes by altering LPS availability to the cells. Our studies suggest that increased production of $\mathrm{C} 3$ by macrophages in tissues colonized or infected with gram-negative organisms may play a role in both tissue regulation of local C3 concentrations and enhanced responsiveness of the infected host.

\section{Acknowledgments}

The authors wish to thank C. R. H. Raetz for helpful advice, K. S. Kunke and D. J. Borrelli for technical assistance, P. M. Henson and H. R. Colten for support and critical review of the data, and H. Hourihan for preparation of the manuscript.

This work was supported in part by grants from the National Institutes of Health (AM 26609, HL 27353, AI 20032, HD 17461, and HL 22487), an Allergic Diseases Academic Award (1-KO7-AI00543) to Dr. Strunk, a Clinical Investigator Award (KO8-HD00584) to Dr. Cole, a research grant from the United Cerebral Palsy Foundation (R-335) to Dr. Cole, and a Helen Hay Whitney Foundation fellowship (F488) to Dr. Whitehead.

\section{References}

1. Ezekowitz, R. A. B., R. B. Sim, M. Hill, and S. Gordon. 1984. Local opsonisation by secreted macrophage complement components. Role of receptors for complement in uptake of zymosan. J. Exp. Med. 159:244-260.
2. Colten, H. R., F. S. Cole, R. Sackstein, and H. S. Auerbach. Tissue and species specific regulation of complement biosynthesis in mononuclear phagocytes. Proc. Fourth Leiden Conf. Mononuclear Phagocytes. Martinus Nijhoff Publishers, The Netherlands. In press.

3. Cole, F. S., and H. R. Colten. Complement biosynthesis. In The Complement System. G. O. Till and K. O. Rother, editors. SpreingerVerlag, Heidelberg, Federal Republic of Germany. In press.

4. Porter, R. R., and K. B. M. Reid. 1978. The biochemistry of complement. Nature (Lond.). 275:699-704.

5. Brade, V., R. E. Hall, and H. R. Colten. 1977. Biosynthesis of pro-C3, a precursor of the third component of complement. J. Exp. Med. 146:759-765.

6. Goldberger, G., M. L. Thomas, B. F. Tack, J. Williams, H. R. Colten, and G. N. Abraham. 1981. NH2-terminal structure and cleavage of guinea pig pro- $\mathrm{C} 3$, the precursor of the third complement component. J. Biol. Chem. 256:12617-12619.

7. Einstein, L. P., C. A. Alper, K. J. Block, J. T. Herrin, F. S. Rosen, J. R. David, and H. R. Colten. 1975. Biosynthesis of the third component of complement (C3) in vitro by monocytes from both normal and homozygous C3-deficient humans. J. Clin. Invest. 60:963-969.

8. Ruddy, S., and H. R. Colten. 1974. Rheumatoid arthritis: biosynthesis of complement proteins by synovial tissues. N. Engl. J. Med. 290: 1284-1288.

9. Morrison, D. C., and J. Ulevitch. 1978. The effects of bacterial endotoxins on host mediation systems. Am. J. Pathol. 93:527-617.

10. Morrison, D. C., and J. L. Ryan. 1979. Bacterial endotoxins and host immune response. Adv. Immunol. 28:293-450.

11. Alexander, P., and R. Evans. 1971. Endotoxin and double stranded RNA render macrophages cytotoxic. Nature (New Biol.). 232: 76-78.

12. Pabst, M. J., H. B. Hedegaard, and R. B. Johnston. 1982. Cultured human monocytes require exposure to bacterial products to maintain an optimal oxygen radical response. J. Immunol. 128:123-128.

13. Wahl, L. M., S. M. Wahl, S. E. Merganhagen, and G. R. Martin. 1974. Collagenase production by endotoxin activated macrophages. Proc. Natl. Acad. Sci. USA. 71:3598-3601.

14. Leslie, C. C., R. A. Musson, and P. M. Henson. 1984. Production of growth factor activity for fibroblasts by human monocyte-derived macrophages. J. Leuk. Biol. 36:143-159.

15. Nishijima, M., F. Amano, Y. Akamatsu, K. Akagawa, T. Tokunaga, and C. R. H. Raetz. 1985. Macrophage activation by monosaccharide precursors of Escherichia coli lipid A. Proc. Natl. Acad. Sci. USA. 82:282-286.

16. Miyama, A., Y. Kawamoto, H. Ichikawa, K. Okamoto, S. Hara, and T. Inoue. 1980. Complement proteins and macrophages. II. The secretion of factor B by lipopolysaccharide-stimulated macrophages. $\mathrm{Mi}$ crobiol. Immunol. 24:1223-1232.

17. Sundsmo, J. S., J. R. Chin, R. A. Papin, D. S. Fair, and Z. Werb. 1985. Factor B, the complement alternative pathway serine proteinase, is a major constitutive protein synthesized and secreted by resident and elicited mouse macrophages. J. Exp. Med. 161:306-322.

18. Thorbecke, G. J., G. M. Hochwald, R. van Furth, H. J. MullerEberhard, and E. B. Jacobson. 1965. Problems in determining the sites of synthesis of complement components. In CIBA symposium Complement, G. E. W. Wolstenholme and J. Knight, editors. J. A. Churchill Ltd., London. 99-119.

19. Passwell, J. H., H. R. Colten, E. E. Schneeberger, Z. Marom, and $\mathrm{E}$. Merler. 1980. Modulation of human monocyte functions by Fc fragments of IgG: a comparison to other monocyte "activators." Immunology. 41:217-225.

20. Skidmore, B. J., J. M. Chiller, D. C. Morrison, and W. O. Weigle. 1975. Immunologic properties of bacterial lipopolysaccharide (LPS): correlation between the mitogenic, adjuvant, and immunogenic activities. J. Immunol. 114:770-775.

21. Takayama, K., N. Qureshi, P. Mascagni, M. A. Nashed, L. Anderson, and C. R. H. Raetz. 1983. Fatty acyl derivatives of glucosamine 1-phosphate in Escherichia coli and their relation to lipid A. J. Biol. Chem. 258:7379-7385. 
22. Einstein, L. P., E. E. Schneeberger, and H. R. Colten. 1976. Synthesis of the second component of complement by long-term cultures of human monocytes. J. Exp. Med. 143:114-126.

23. Strunk, R. C., K. S. Kunke, and P. C. Giclas. 1983. Human peripheral blood monocyte-derived macrophages produce haemolytically active $\mathrm{C} 3$ in vitro. Immunology. 49:169-174.

24. Strunk, R. C., K. S. Kunke, and R. A. Musson. 1980. Lack of requirement for spreading for macrophages to synthesize complement. J. Reticuloendothel. Soc. 28:483-488.

25. Musson, R. A., H. Shafran, and P. M. Henson. 1980. Intracellular levels and stimulated release of lysosomal enzymes from human peripheral blood monocytes and monocyte-derived macrophages. J. Reticuloendothel. Soc. 28:249-255.

26. Cole, F. S., H. S. Auerbach, G. Goldberger, and H. R. Colten. 1985. Tissue specific pretranslational regulation of complement production in human mononuclear phagocytes. J. Immunol. 134:2610-2616.

27. Roberts, B. E., and B. M. Paterson. 1973. Effect of translation of tobacco mosaic virus RNA and rabbit globin 9S RNA in a cell-free system from commercial wheat germ. Proc. Natl. Acad. Sci. USA. 70: 2330-2334.

28. Perlmutter, D. H., R. M. Kay, F. S. Cole, T. H.Rossing, D. van Thiel, and H. R. Colten. The cellular defect in alpha-l-proteinase inhibitor (alpha, PI) deficiency is expressed in Xenopus oocytes injected with human liver RNA and in human monocytes. Proc. Natl. Acad. Sci. USA. In press.

29. Woods, D. E., A. F. Markham, A. T. Ricker, G. Goldberger, and H. R. Colten. 1982. Isolation of CDNA clones for the human complement protein factor B, a class III major histocompatibility complex gene product. Proc. Natl. Acad. Sci. USA. 79:5661-5665.

30. Grunstein, M., and D. S. Hogness. 1975. Colony hybridization: a method for the isolation of cloned DNAs that contain a specific gene. Proc. Natl. Acad. Sci. USA. 72:3962-3965.

31. Rigby, P. W. J., M. Dieckmann, C. Rhodes, and P. Berg. 1977. Labeling deoxyribonucleic acid to high specific activity in vitro by nick translation with DNA polymerase I. J. Mol. Biol. 113:237-251.

32. Jeffreys, A. J., and R. A. Flavell. 1977. A physical map of the DNA regions flanking the rabbit beta globin gene. Cell. 12:429-439.

33. Clewell, D. B., and D. Helinski. 1969. Supercoiled circular DNAprotein complex in Escherichia coli: purification and induced conversion to an open circular DNA form. Proc. Natl. Acad. Sci. USA. 69:11591166.

34. Sanger, F., S. Nicklen, and A. R. Coulson. 1977. DNA sequencing with chain-terminating inhibitors. Proc. Natl. Acad. Sci. USA. 74:54635467.

35. Wetsel, R. A., A. Lundwall, F. Davidson, T. Gibson, B. F. Tack, and G. H. Fey. 1984. Structure of murine complement component C3. II. Nucleotide sequence of cloned complementary DNA coding for the alpha chain. J. Biol. Chem. 259:13857-13862.

36. Chirgwin, J. M., A. E. Przygyla, R. J. MacDonald, and W. J. Rutter. 1979. Isolation of biologically active ribonucleic acid from sources enriched in ribonuclease. Biochemistry. 18:5294-5298.
37. Thomas, P. 1980. Hybridization of denatured RNA and small DNA fragments transferred to nitrocellulose. Proc. Natl. Acad. Sci. USA. 77:5201-5205.

38. Woods, D. E., M. D. Edge, and H. R. Colten. 1984. Isolation of a cDNA clone for the human complement protein $\mathrm{C} 2$ and its use in the identification of a restriction fragment length polymorphism. J. Clin. Invest. 774:634-638.

39. Strunk, R. S., A. H. Tashjian, and H. R. Colten. 1975. Complement biosynthesis in vitro by rat hepatoma cell strains. J. Immunol. 114: 331-335.

40. Zimmer, B., H. P. Hartung, G. Scharfenberger, D. Bitter-Suermann, and U. Hadding. 1982. Quantitative studies of the secretion of complement component $\mathrm{C} 3$ by resident, elicited, and activated macrophages. Comparison with $\mathrm{C} 2, \mathrm{C} 4$ and lysosomal enzyme release. Eur. J. Immunol. 12:426-430.

41. Kurland, J. I., and R. Bockman. 1978. Prostaglandin E production by human blood monocytes and mouse peritoneal macrophages. J. Exp. Med. 147:952-957.

42. Dinarello, C. A. Interleukin-1. 1984. Rev. Infect. Dis. 6:51-95.

43. Gordon, S., J. C. Unkeless, and Z. A. Cohn. 1974. Induction of macrophage plasminogen activator by endotoxic stimulation and phagocytosis. J. Exp. Med. 140:995-1010.

44. Cooper, P. H., P. Mayer, and M. Baggiolini. 1984. Stimulation of phagocytosis in bone marrow-derived mouse macrophages by bacterial lipopolysaccharide: correlation with biochemical and functional parameters. J. Immunol. 133:913-922.

45. Yuan, D., and P. W. Tucker. 1982. Effect of lipopolysaccharide stimulation on the transcription and translation of messenger RNA for cell surface immunoglobulin M. J. Exp. Med. 156:962-974.

46. Nelson, K. J., E. I. Mather, and R. P. Perry. 1984. Lipopolysaccharide-induced transcription of the kappa immunoglobulin locus occurs on both alleles and is independent of methylation status. Nucl. Acids Res. 12:1911-1922.

47. Durnam, D. M., J. S. Hoffman, C. J. Quaife, E. P. Benditt, H. Y. Chen, R. L. Brinster, and R. D. Palmiter. 1984. Induction of mouse metallothionein-I mRNA by bacterial endotoxin is independent of metals and glucocorticoid hormones. Proc. Natl. Acad. Sci. USA. 81: 1053-1056.

48. Sultzer, B. M. 1968. Genetic control of leucocyte responses to endotoxin. Nature (Lond.). 219:1253-1254.

49. Vogel, S. N., L. L. Weedon, R. N. Moore, and D. L. Rosenstriech. 1982. Correction of defective macrophage differentiation in $\mathrm{C} 3 \mathrm{H} / \mathrm{HeJ}$ mice by an interferon-like molecule. J. Immunol. 128:380-387.

50. Vogel, S. N., G. S. Madonna, L. M. Wahl, and P. D. Rick. 1984. In vitro stimulation of $\mathrm{C} 3 \mathrm{H} / \mathrm{HeJ}$ spleen cells and macrophages by a lipid A precursor molecule derived from Salmonella typhimurium. J. Immunol. 132:347-353.

51. Wightman, P. D., and C. R. H. Raetz. 1984. The activation of protein kinase $\mathrm{C}$ by biologically active lipid moieties of lipopolysaccharide. J. Biol. Chem. 259:10048-10052. 